\title{
Arithmetic failure and the myth of the unsustainability of universal health insurance
}

\section{François Béland PhD}

$\infty$

See related article page 5I ince its inception, the sustainability of Canada's universal health insurance (medicare) has been a concern. A search for "sustainability" and "unsustainability" on the CMAJ Web site yielded some 40 editorials, papers, letters, synopses, and reviews. Arguments for or against sustainability are usually supported by health care data of a variety of types, such as costs, ${ }^{1}$ percentage of gross domestic product (GDP) ${ }^{2-4}$ and proportions of provincial government spending. ${ }^{5}$

For example, McKinnon ${ }^{5}$ has argued for the unsustainability of medicare using the ratio of health care spending to government income. Her argument can be summarized in 3 points: government health care expenditure is an increasing proportion of total government program spending; it is increasing faster than government income; and when projected as percentage of income over the next 20 years, the trend appears to be unsustainable.

More-or-less the same criteria are used in the Ménard report $^{6}$ on the sustainability of government spending in Quebec on health and social care. This report laid the foundation for part of the recent white paper ${ }^{7}$ on the Chaoulli Supreme Court judgment by Quebec's Ministère de la Santé et des Services sociaux.

I shall examine McKinnon's 3 points in terms of data from Quebec.

\section{Governmental spending in health care}

Point I: Data from the Quebec Ministry of Finance (Figure I). ${ }^{8.9}$ show that from fiscal years $1975 / 76$ through $1994 / 95$, government health care expenditure was stable at about $32 \%$ of program spending (i.e., government budgetary expenditures minus debt-servicing costs). Since then, government health care expenditures have increased from 33.I\% in $1994 /$ 95 to $38.3 \%$ in $2004 / 05$. Thus, increases in rates of government health care expenditure relative to program spending go back no more than Io years.

Sustainability of medicare - a Canadian national pastime, according to a $2000 C M A J$ editorial $^{10}$ - should be assessed, not by means of data on total government expenditures on health care, but with data on medicare expenditures. Provincial governments fund health-related services other than those of hospitals and physicians. These have been financed through a mix of government funding, out-of-pocket payments and copayments with private insurance companies. "Medicare" expenditures in Quebec, ${ }^{8}$ which were $22.7 \%$ of program spending in $1975 / 76$, reached $26.1 \%$ in $2005 / 06$; as a percentage of government revenue, however, they decreased from $24.3 \%$ to $23.9 \%$ over the same period (Figure I).
Point 2: From $1975 / 76$ to $2005 / 06$, government health care expenditure varied between $28.8 \%$ and $33.8 \%$ of Quebec government income (Figure I). The average annual increase from I997 to 2005 was 5.6\%, during which time the increase in government revenue averaged $4.4 \%$ annually. On a longer scale, these expenditures increased at an average annual rate of $6.8 \%$ over the last 30 years, barely above the rate of increase of government income during the same period: $6.6 \%$. Governmental expenditures on health care and revenues both declined in relative terms during the last 8 years of the 30-year period - revenues somewhat more than health care expenditures, in line with income tax reductions introduced at the end of the Iggos by the Landry government. In 2005/06, these reductions represented some $\$ 5$-billion in lost revenue.

Point 3: Projections of future spending require data that are comprehensive and reliable. For example, projections of rates of increase of government health care expenditure over income have generally used data from the provincial ministries of finance. Government budgets result, however, from a mix of accounting rules and political statements on financial matters. In their annual budgets, provincial governments report neither total expenditures nor total health care expenditures. The estimate by the Canadian Institute for Health Information of the percentage of government health care expenditure in Quebec relative to program spending in 2003/04 was $32 \%$; that estimated by Quebec's Ministry of Finance was $37 \%$. Thus, long-term trends can differ widely, depending on the data source.

The Financial Management System of Statistics Canada reports comparative data on the revenues and expenditures of provincial governments. ${ }^{11}$ These data include all government ministries, autonomous organizations, special funds, nonautonomous pension funds, universities, colleges and health care agencies. Thus, given Statistics Canada's analytical framework ${ }^{11}$ all health care expenditures that stem from provincial health care policies, programs and delivery agencies are included. All provincial government revenues from what-

François Béland is a Professeur Titulaire [full professor] in the Département d'administration de la santé [Department of Health Administration] and codirector of SOLIDAGE, the Université de Montréal-McGill University Research Group on Integrated Services for Older Persons, Centre for Clinical Epidemiology and Community Studies, Lady Davis Institute, Jewish General Hospital, Montréal, Que.

Une version française de cet article est disponible à l'adresse www.cmaj.ca/cgi/content/full/I77/I/54/DCI 


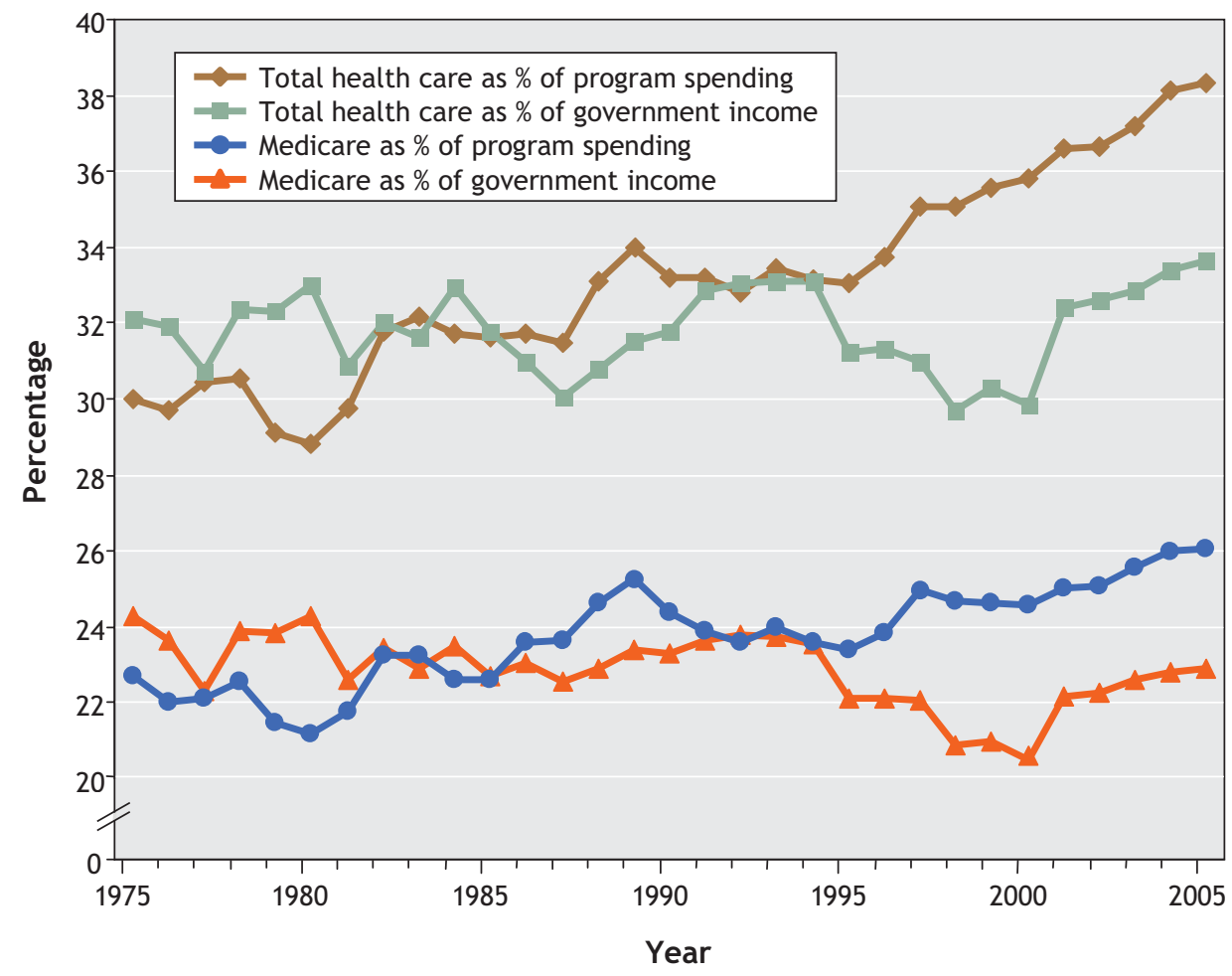

Figure 1: Medicare and total government health care expenditures in Quebec during fiscal years 19752006, as shares of program spending (government budgetary expenditures, less debt-servicing costs) and government income. Data points centre on fiscal years, which end on March 31. Sources: Ministère des Finances du Québec, 2006-2007 Budget Plan, Table 3.1.1; ${ }^{9}$ and Canadian Institute for Health Information, National Health Expenditure Trends, $1975^{-2006}$, Table B.4.4. ${ }^{8}$

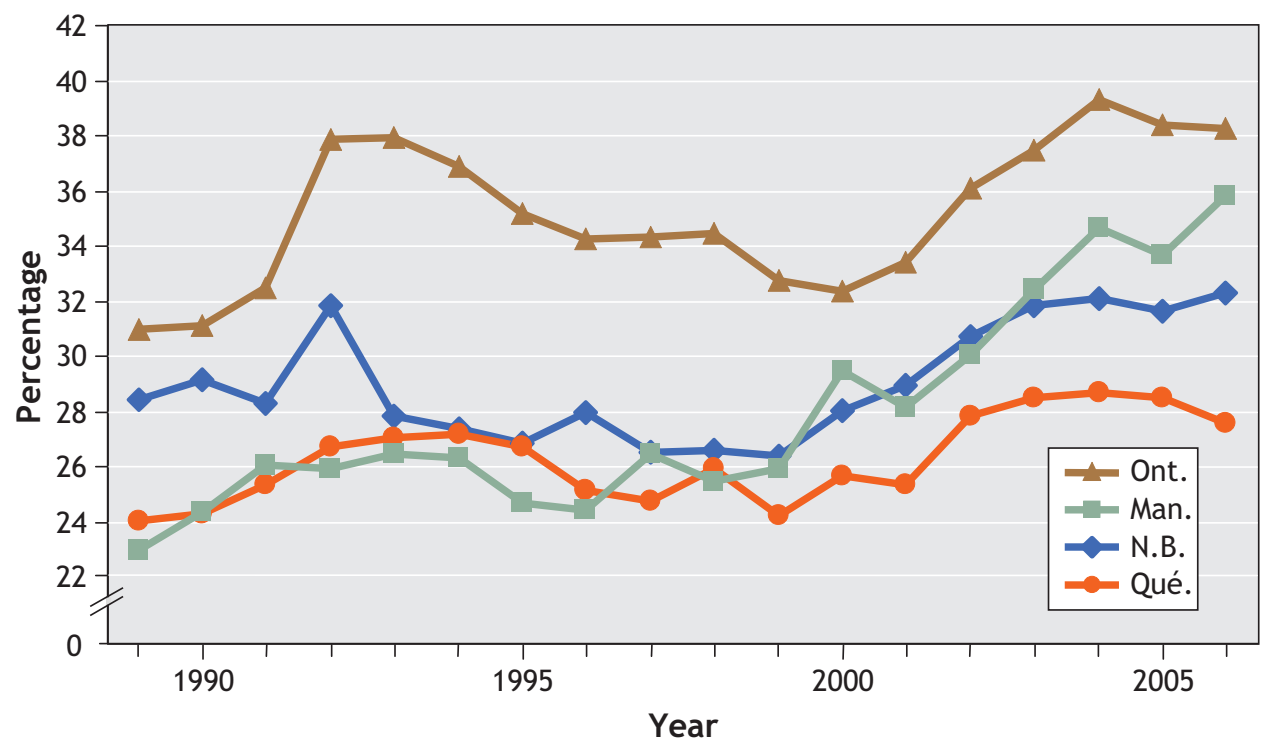

Figure 2: Trends in government spending on health care in Ontario, Manitoba, New Brunswick and Quebec, 1989-2006 (Financial Management System figures). ${ }^{11}$ Data on these provinces are from Statistics Canada, Table 385-0001: consolidated federal, provincial, territorial and local government revenue and expenditures, annual (2056 series). Available: http://cansim2.statcan.ca/cgi-win/cnsmcgi.exe?regtkt $=\& c 2 s u b=\& a r r a y i d=3850001 \& c 2 d b=\& v e c=\& l a n g=e \& s d d s l o c=\&$ rootdir $=c i i / \&$ resulttemplate $=c i i / c i i \_p i c k$ \&array_pick=1\&sddsid=\&sddsdesc= (accessed July 5 ). 
ever sources are also considered. These are the kinds of data needed to assess a government's financial commitment to health care in toto.

According to Financial Management System data for provincial and territorial government spending, health care spending for Quebec and Ontario over the Iggos was constant or declining relative to government income. Relative spending then increased in Ontario, only to slow down again, beginning in 2004. In Quebec and New Brunswick, rates of increase slowed from 2002. The trend in Manitoba has been rising since I999. Comparison of data for Quebec (Figure I and Figure 2) shows important differences in trends as well as absolute values.

\section{Conclusion}

Accurate and agreed-upon definitions of government health care expenditure are needed in the assessment of trends. Both numerators and denominators must be selected in terms of the domains of health care being assessed. Medicare assessment requires medicare expenditure data in the numerator, and data on government total income from all sources in the denominator. Moreover, total governmental commitment to health care financing includes provincial, federal and municipal spending. The appropriate denominator here should be based on incomes from the 3 jurisdiction levels.

Statements by MacKinnon (that government health care spending in terms of income has increased in all jurisdictions) $)^{5,12}$ and by the Ministère de la Santé et des Services sociaux in the white paper on the Chaoulli judgment ${ }^{7}$ and Ménard report ${ }^{6}$ are not supported by the data. Neither is the argument ${ }^{13}$ that the problem is in the numerator (i.e., in government health care expenditures).

Clearly, different figures on government health care expenditure and their trends are obtained from different sources of data. There is a need for reliable and valid data on total government spending on health care, spending on medicare and total program spending, and government revenue. It can not be assumed that data from provincial ministries of finance, which were used by MacKinnon ${ }^{13}$ and the Ménard report, ${ }^{6}$ are appropriate for estimations of spending related to provincial health care policies.

This article has been peer reviewed.

Competing interests: None declared.

\section{REFERENCES}

I. Barer ML, Evans RG, McGrail KM, et al. Beneath the calm surface: the changing face of physician-service use in British Columbia, I985/86 versus I996/97. CMAJ 2004; $170: 803-7$.

2. Medicare on the hustings [editorial]. $C M A J$ 2004;170:I637.

3. Deber R, Swan B. Canadian health expenditures: Where do we really stand internationally? CMAJ I999;160:1730-4.
4. Guyatt G, Yalnizyan A, Devereaux PJ. Solving the public health care sustainability puzzle. $C M A J$ 2002;167:36-8.

5. MacKinnon JC. The arithmetic of health care. CMAJ 2004;171:603-4.

6. Comité de travail sur la pérennité du système de santé et de services sociaux du Québec. Pour sortir de l'impasse: la solidarité entre nos générations. Gouvernment du Quebec; 2007. Available: www.briller.gouv.qc.ca/documentation/publications /rapport_sante.pdf (accessed 2007 May 9).

7. Ministère de la santé et des services sociaux du Québec. Guaranteeing access: meeting the challenges of equity, efficiency and quality - consultation document. Available: http://publications.msss.gouv.qc.ca/acrobat/f/documentation /2005/05-72I-orA.pdf (accessed 2007 June 6).

8. Canadian Institute for Health Information (CIHI). National health expenditure trends, I975-2006. Ottawa: CIHI; 2006. Available: http://dsp-psd.pwgsc.gc.ca /Collection/Hir8-2-2006E.pdf (accessed 2007 June 6).

9. Ministère des Finances du Québec. 2006-2007 budget plan. Available: www.budget .finances.gouv.qc.ca/budget/2006-2007/index_en.asp (accessed 2007 June 6).

Io. Time for a new Canada Health Act [editorial]. CMAJ 2000;163:689.

II. Statistics Canada. Financial Management System. Ottawa: The Ministry; 2006

I2. Evans RG, Vujicic M. Political wolves and economic sheep: the sustainability of public health insurance in Canada. In: Maynard A, editor. The public-private mix for health care. Vancouver: Working Paper CHSPRo3:I6W, Center for Health Services and Policy Research, University of British Columbia; January 2005.

I3. MacKinnon J. More arithmetic of health care [letter]. CMAJ 2005;172:730.

Correspondence to: Dr. François Béland, Département

d'administration de la santé, Université de Montréal, CP 6I28,

Succ. Centre-Ville, Montréal QC $\mathrm{H}_{3} \mathrm{C}$ 3J7; fax 514 343-2207;

francois.beland@umontreal.ca

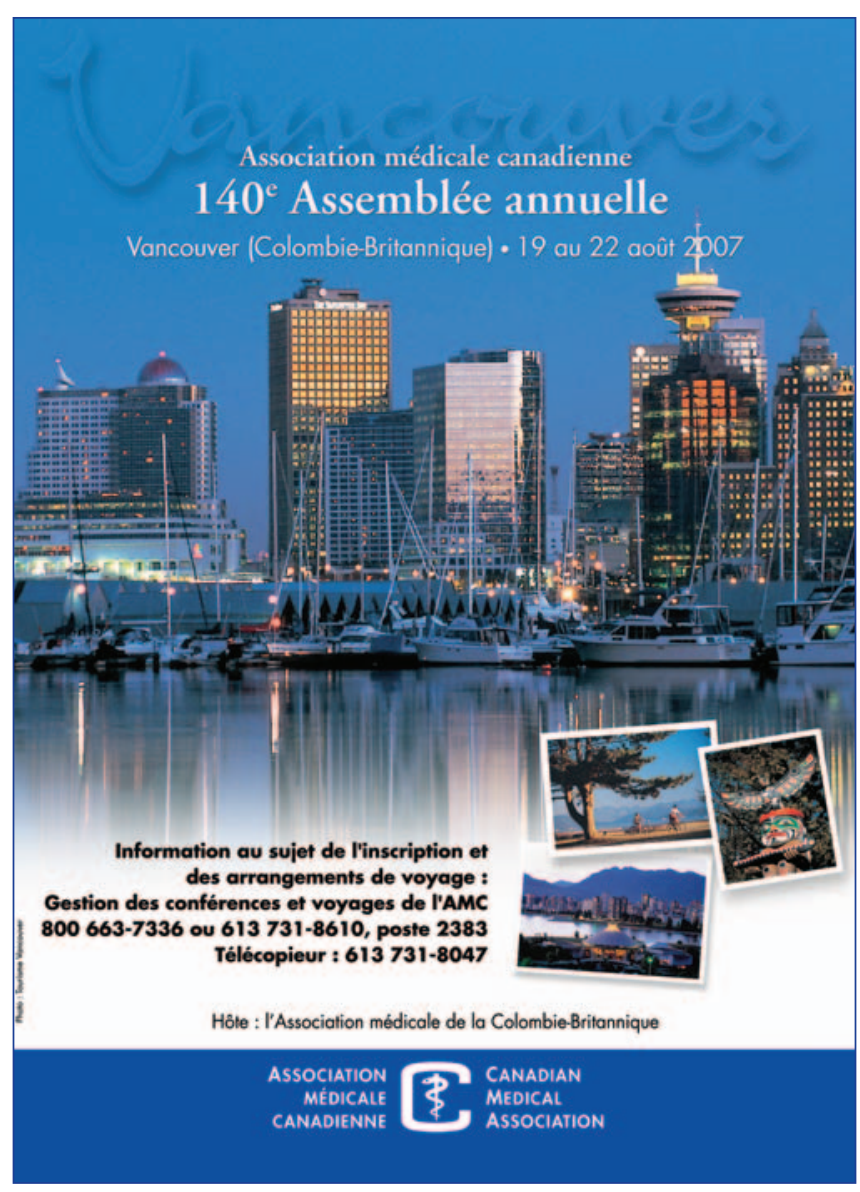

